\title{
Homenagem a João Paisana Uma conversa fenomenológica
}

\section{Joaquim Carlos Araújo}

Se questionar é abrir possibilidades, isto é, abrir as múltiplas respostas possíveis ao que está em questão, responder é eleger uma dessas possibilidades enquanto fundamento do não ser das outras. A possibilidade eleita, a resposta afirmada, opõe-se a todas as outras possiveis respostas abertas pelo questionar. Se questionar é abrir possibilidades, responder é encerrar possibilidades, isto é, encerrar a questão. João Paisana, Husserl e a Ideia de Europa.

Falo contigo com armas... por teres tão celeremente fechado as tuas possibilidades e encerrado a questão. Conseguiste ser tão original, e originário ao fim e ao cabo, já que fundaste o teu mundo nos outros, que nem o deus poderia precaver-se com o espanto de que muitas respostas são dadas de modo tão efectivo. Que ironia querido amigo, provar que o absurdo existe. E agora, não posso discutir contigo os teus textos que (re)leio.

Por isso, quase como vingança, vou exigir nestas inúteis, insuficientes linhas um retorno à experiência singular do objecto, por exemplo (dizias que a fenomenologia se fazia com exemplos) a morte (do outro que és tu). É que todas as possibilidades noemáticas se afiguram reais quando em aberto. Mas, como tu próprio o disseste, ao responderes a uma fechas todas as outras. A morte é isso. E que condição mais redutora do que esta? Talvez se vivesses mais tempo continuasses no teu limite noético da redução como prática de uma vida, com muito de estético, muito de pathos-com, e de Epicuro também (ou acima de tudo!). Colocarias, interminavelmente, o mundo em suspenso, mais enquanto atitude teórica que te re-conduziria a ti mesmo do que um simples método de o pôr entre parêntesis.

Excluída a posição da existência retornarias a ela como quen sabe que a conversão reflexiva nunca se dá impunemente. As tuas ideações teimariam em basear-se na experiência interna de um ego feliz. E depois, e ainda, optarias pelas espécies ideais de vivências e suas relações (sempre com os outros, com os amigos portanto). Dir-me-ias nessa altura, com uma verdadeira gargalhada fenomenológica como só tu as sabias dar, que nenhuma condição de possibilidade se afiguraria com mais evidência de que o próprio campo fenomenológico básico, a saber, a experiência, 
nomeadamente a linguística - já que nenhuma coisa existe sem ela: nem o mundo, nem a imaginação, e muito menos qualquer copo de um curial tinto ou algum charuto ainda por ritualizar pelo fogo.

E eis o exercício quotidiano que funda a própria vida! Mais, e tu sabia-lo bem, ao tomares consciência dos teus vividos perceptivos, bastas vezes te demoravas no modo atencional, mas outras tantas (e estas tão verdadeiramente ontológicas) no modo emocional, e outras, simplesmente sensoriais. Todos os pirronistas juntos não fariam melhor epekhô. Só aos filósofos como tu seria permitida tal atitude de vigilância radical dos seus próprios pré-conceitos.

Entretanto, a aprendizagem de fenomenólogo prolongar-se-ia agora variando a captação dos objectos até ao que de essencial ou eidético eles possuem, o mesmo é dizer, até às potencialidades não actualizadas do seu modo de aparecer (como tu gostavas meu amigo de conversar sobre o não-actual sempre aberto!). Na verdade, o que somos nós senão entes incompletos que de um momento para o outro até conseguimos morrer, e além disso também experienciamos aquele estranho apelo do acto criativo da imaginação plausível que teoriza todo o acaso, todo o possível. Tematizamos o mundo sim mas também podíamos não o fazer, terias razão aqui. E eu acrescentaria que o fortuito se mantinha, qual santo absoluto da vida já que o divino não foi talhado à imagem da filosofia. Certamente. Misturar as coisas, dirias, é como falar de um «pau de ferro».

Finalmente a descrição. Um dos grandes avatares da tua conduta de mestre fenomenólogo. Conduta que extravasava já, no entanto, toda a escola fenomenológica. Acção de homem e professor consciente da interesseira passividade económica do Norte Ocidental, isto para além do cómodo agasalho da faculdade.

O outro grande avatar seria a explicitação interpretativa. Esse que, para lá do teu empenho puramente académico te faria conferir, mais recentemente, à tua escrita a luta e a força da desvelada opinião jornalística a favor dos menos católicos. A terrena arte de ser fenomenólogo descrevendo o mundo! De facto, como pintar uma paisagem sem ver a cor que ela tem? E se o pintor for realista a cor não se torna evidente. É óbvio!, como gostavas de repetir. Outras vezes encolherias os ombros, já que o que é óbvio também pode não ser dito.

E o problema da diversidade não-actual das aparições descritas (Husserl dixit)? Ah!, essa seria a tua arte maior: a escolha do pressuposto, da tradição, do início da aventura - fizeste toda a tua obra e toda a tua vida com esse tom jogando no duro, muitas vezes no escuro (gostavas de cartas!) - e arriscaste inclusive usufruir de uma estabilidade emocional (como se pode trabalhar tão bem sem ela?) com uma companheira que te ofereceu inúmeras, inefáveis horas de solidão a dois.

Depois... depois a destruição, a morte, a morte dos pressupostos (a vida é uma tradição!...), a guerra à evidência choruda dos burgueses mercadores da filosofia e dos prodigiosos magos da universidade. Obrigado professor. Um abraço, este copo e uma lágrima. 